\title{
Naujos brachiopodų rūšys Lietuvoje
}

\author{
Juozas Paškevičius \\ Vilniaus universitetas, \\ M. K. Čiurlionio g. 21, \\ LT-03101 Vilnius, Lietuva \\ El.paštas juozas.paskevicius@gf.vu.lt
}

Paškevičius J. Naujos brachiopodų rūšys Lietuvoje. Geologija. Geografija. 2017. T. 3(2). ISSN 2351-7549.

Straipsnyje rašoma apie ordoviko ir silūro periodų Baltijos kontinente ties pusiauju aplinkos sąlygas ir amžių, kai gyveno aprašomosios brachiopodų rūšys, jų palaidojimą ir gyli šiandieniniuose sluoksniuose. Pateikiama naujų ordoviko brachiopodų rūšių Dolerorthis nadruvensis (Paškevičius, Hints, 2016); Sampo suduvensis (Paškevičius, Hints, 2016); Thaerodonta notabile (Paškevičius, 2016) ir silüro - Isorthis ovalis (Pashkevichius, 1962); Strophochonetes stonishkensis (Pashkevichius, 1962; papildyta Rybnikova, 1967) ir Lissatrypa lithuanica (Paškevičius, Modzalevskaya, Musteikis, 2002), jų taksonomija, duoti holotipai, amžius ir paplitimas, pažymimos ekologinès gyvenimo sąlygos. Nurodomi leidiniai, kuriuose buvo paskelbtos naujos rūšys, informacija apie jų saugojimą Vilniaus universiteto Geologijos muziejaus kolekcijose. Pateikti šiu naujų rūšių keturi paleontologiniai paveikslai.

Raktažodžiai: ordovikas, silūras, Brachiopoda, naujos rūšys, sistematika, holotipai, paplitimas, ekologija

\section{IVADAS}

Tyrimo objektas yra naujų brachiopodų rūšių, gyvenusių paleozojinès eros ordoviko ir silūro perioduose (t. y. prieš 453-419,2 milijonus metų) paleontologinis tyrimas. To meto Baltikos kontinente, o jis tịsojo netoli nuo Žemès rutulio pusiaujo, būsimos Lietuvos teritorijos šiltose jūrose vešèjo itin gausi gyvūnija. Minimos jūros buvo skirtingo gylio, būsimoje Lietuvos rytų ir pietryčių teritorijoje telkšojo sekli šelfo jūra su karbonatinių nuosèdų sedimentacija, iš kurių vèliau dèl diagenezès ir epigenezès poveikio susidarè kieta uoliena - klintis, daugiausia su palaidota bentoso (dugnine) fauna. Teritorijoje šiek tiek ị vakarus šelfo jūra buvo gilesne. Joje vyko molingų ir karbonatinių molingų nuosèdų su gausia organine medžiaga klostymasis, vèlesnių geologinių procesų metu persiformavusių ỉ tamsius argilitus, mergelius ir kitas uolienas. Jose yra palaidota planktoninė graptolitų, nektonine konodontų ir pirmujuc stuburinių fauna, taip pat plonasienių brachiopodų, moliuskų, ostrakodų, trilobitu ir kita fauna. Šios uolienos kartu su palaidotais organizmais per milijonus metų persikristalizavo, ypač kiautelių faunos liekanos, tapo kalcilizuotos, o kai kurie graptolitai net piritizuoti.

Dabartiniu metu minètos ordoviko ir silūro uolienos su palaidota gyvūnija ir augalija slūgso labai skirtinguose gyliuose, priklausomai nuo geografinès padèties: giliausiai - Lietuvos pietvakariuose, o sekliausiai - pietryčiuose. Pasirodo, kad Baltikos kontinentas ir jo atskiros dalys ne kartą grimzdo žemiau jūros lygio, buvo užlietas jūrų vandens, o kitais laikotarpiais kilo, susidarè sausuma. Todèl sumuojantis grimzdimo ir kilimo amplitudei rytineje ir pietrytineje Lietuvos dalyse, t. y. Baltarusijos-Mozūrijos anteklizès šlaite, 
pavyzdžiui, Vilniaus-1 gręžinyje uolienos su aprašoma fauna slūgso nuo 105 iki 277 metru gylyje; Baltijos sineklizès šlaite, Vidurio Lietuvoje, Krekenavos-7 gręžinyje - nuo 539,3 iki 931 metru gylyje, o ašinèje Baltijos sineklizès dalyje, Stoniškių-1 gręžinyje - net nuo 1212 iki 1987 metrų gylyje.

Uolienų, kuriose rastos ir ištirtos fosilinių brachiopodų faunos naujos rūšys, amžius yra nustatytas santykinès ir absoliučios geochronologijos tyrimo metodais. Santykinei geochronologijai plačiai buvo taikomas paleontologinis ir stratigrafinis tyrimo metodai, jų esmę sudaro rūšių ir genčių evoliucija erdvejje ir bėgant laikui. Jaunesnis žemès sluoksnis paprastai yra palaidojęs mirusias to laikotarpio organinio pasaulio rūšis, išsivystymu besiskiriančias nuo žemiau (senesnių) ir aukščiau (jaunesnių) esančių sluoksnių rūšių. Tuo remiantis buvo nustatytas santykinis sluoksnių amžius (senesni, jaunesni sluoksniai arba senesnès ir jaunesnès organizmų rūšys). Tai suteikè galimybę grupuoti sluoksnius pagal amžių, nustatyti jų susidarymo eiliškumą, sudaryti atskirų geologinių periodų geochronologinę skalę, atlikti sluoksnių arba fosilijų koreliaciją baseino viduje ir nutolusiose teritorijose, tarp baseinų atsižvelgiant $\mathfrak{i}$ ekologines rūšių gyvenimo sąlygas.

Prie sluoksnių, rūšių absoliutaus amžiaus tyrimo metodų reikia priskirti ir radioaktyvių izotopų tyrimą, kuris pateikia amžių absoliučiais skaičiais, t. y. metais. Vienas iš dažniausiai taikomų šių tyrimo metodų fanerozojaus nuosèdineje storymëje yra kalio-argono tyrimo metodas, jis pasitelkiamas vertinant uolienoje esanti mineralą glaukonitą ir jame aptinkamą radioaktyvuji kali. Prekambro kristalinių uolienų amžiui nustatyti dažnai taikomas urano-švino metodas. Yra ir daugiau izotopinių tyrimo metodų. Pastaruoju metu sluoksnių vienalaikiškumui nustatyti, jų koreliacijai, baseinų sedimentacinių sąlygų tyrimui taikomi geocheminiai duomenys - organinès anglies izotopuc tyrimas uolienose, deguonies izotopų nustatymas organizmų kiauteliuose, kuriais remiantis sudaromi jų sudeties variacijos grafikai, suteikiantys galimybę spręsti apie sluoksnių bei fosilijų tapatumą, vienalaikiškumą.

Autorius Lietuvos ordoviko ir silūro brachiopodus giliųjų gręžinių medžiagoje tyrinejjo nuo 1955 metų. Tyrimo duomenis, taip pat ir naujas rūšis, yra paskelbęs daugelyje mokslinių straipsnių lietuvių, anglų ir rusų kalbomis (Paškevičius, 1958, 2000 (plati anglų kalbos santrauka), 2004, 2016;
Pashkevichius, 1962, 1963, 1972; Paškevičius, Lapinskas, Brazauskas, Musteikis, Jacyna, 1994; Musteikis, Paškevičius, 1999; Paškevičius, Klimantavičius, Radzevičius, 2012; Paškevičius, Hints, 2013; Hints, Paškevičius, Martma, Männik, Nolvak, 2016).

\section{NAUJŲ BRACHIOPODŲ RŪŠIU TAKSONOMIJA, HOLOTIPAI, AMŽIUS, PAPLITIMAS}

Autoriaus ištirti ir paskelbti naujų rūšių brachiopodai sistemiškai skiriami atskiram tipui, šešioms jų šeimoms, gyvenusioms ordoviko ir silūro perioduose. Ju paplitimas kol kas apsiriboja Baltijos kraštais, o kai kurios rūšys jau randamos ir už jų ribų.

\section{ORDOVIKO BRACHIOPODŲ RŪŠYS}

Lietuvos ordoviko sistemoje šio straipsnio autoriaus kartu su bendraautore L. Hints (2016) buvo paskelbtos dvi naujos brachiopodų rūšys ir autoriaus (2016) viena rūšis (žr. jų paleontologinị aprašymą).

Ordoviko brachiopodų rūšis - Dolerorthis nadruvensis (iš XIII a. aisčių žemès Nadruva pavadinimo) (Paškevičius, Hints, 2016) skiriama Orthida būriui, Orthoidea antšeimiui, Hesperothidae šeimai, Dolerorthis genčiai. Rūšies holotipas (visu naujų rūšių ir porūšiu holotipai ir paratipai yra VU Geologijos ir mineralogijos katedros muziejaus kolekcijoje) yra Vilniaus universiteto holotipu kolekcijoje, B14/66, nurodytas šio straipsnio 1 paleontologiniame pav., A1-A4, Lukštų svita, Oandu regioninis aukštas, viršutinis ordoviko kačio aukštas. Rūšis daugiausia paplitusi Rytų Baltijos kraštuose, ypač Vidurio Lietuvoje, Oandu regioninio aukšto, Lukštų svitos mergeliuose, rečiau Rakverès reg. aukšto, Jakšių svitos mergeliuose (Paškevičius, Hints, 2016).

Sampo suduvensis (iš XIII a. aisčių žemès Sūduva pavadinimo) (Paškevičius, Hints, 2016) priklauso Strophomenida būriui, Plectambonacea antšeimiui, Leptellinidae šeimai, Leptellinidae pošeimiui, Sampo genčiai. Holotipas VU, B14/23, dorsalinè geldele, 2 paleontologinis pav., A1-A3, Jakšių svita, Rakverès reg. aukštas, vid. ordoviko, kačio aukštas (Paškevičius, Hints, 2016). Paplitusi Lietuvoje ir kituose Rytų Baltijos kraštuose, Kaliningrado sr., kačio aukšto, Alvito ir Šakių svitų mergeliuose, Oandu, taip pat Jakšių svitos Rakverès reg. aukšto apatiniuose sluoksniuose. 


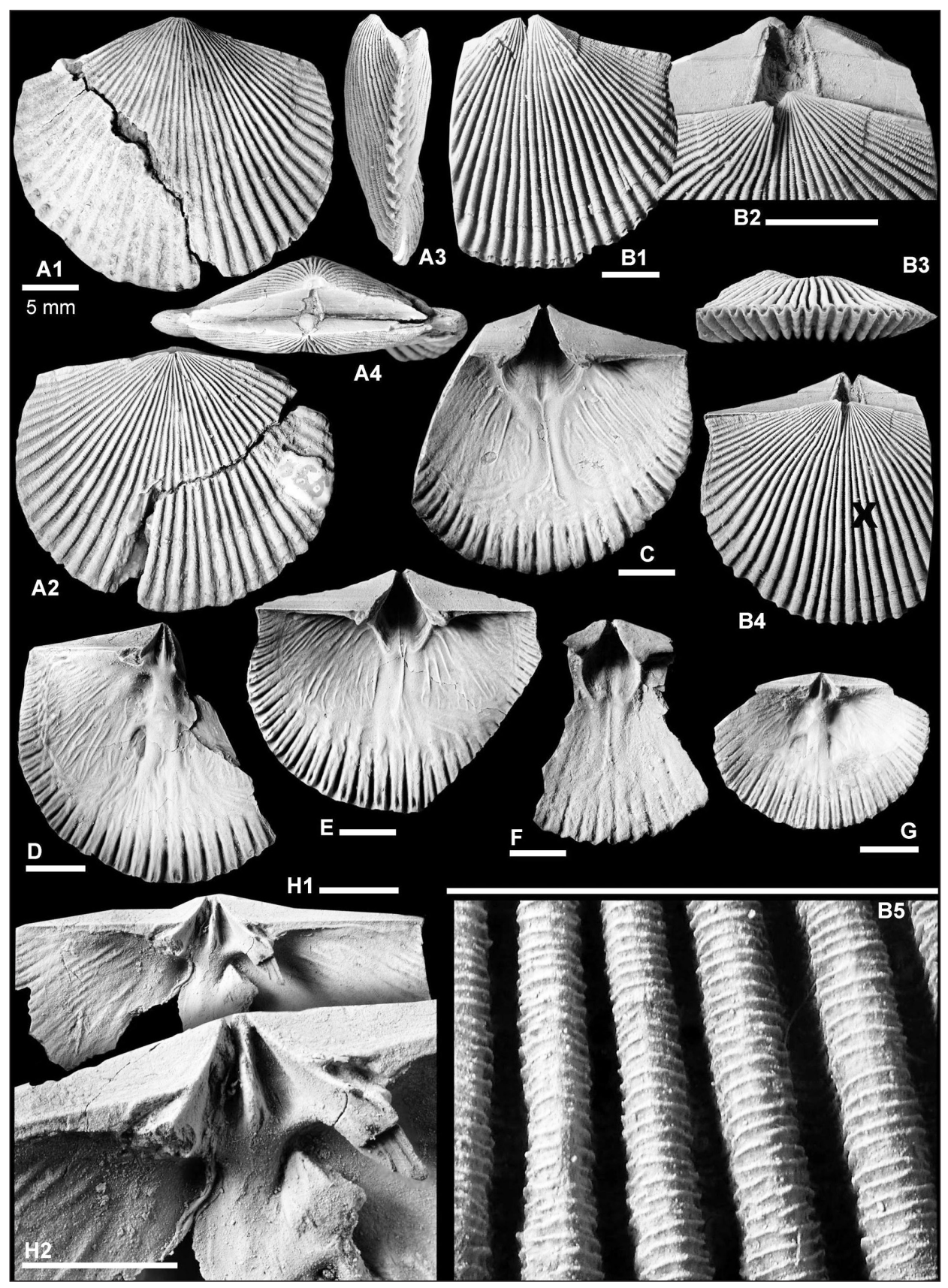

1 pav. Dolerorthis nadruvensis (Paškevičius, Hints, 2016)

A1-A4 holotipas, VU B14/66, ventralinès ir dorsalinės geldelès išorè, jų lateralinis ir užpakalinis vaizdas, Sutkų-89 gręžinys, gylis 1191,6 m, Oandu reg. aukštas, Alvito svita. B - ne visa kriauklè, Estijos geologijos instituto kolekcija (GIT) 716-366: B1 - ventralinès geldelès išorè, B2 - ventralinè interarèja su deltyrijaus sustorèjusiais kraštais, B3, B4 - priešakinis vaizdas ir dorsalès išorè ( $\times$ ženklas ant B4 geldelès rodo B5 lamelių ornamentiką), Pajevonys-13 gręžinys, gylis 1 190,0-1 190,9 m, Oandu aukštas, Šakių svita. C - ventralinès geldelès vidus, GIT 716-436-2, Kybartų-29 gręžinys, gylis 1 266,8-1 268,9 m, Oandu aukštas, svita nenustatyta. D - dorsalinès geldelès vidus, GIT 716-436-1, Kybartų-29 grę̌zinys, gylis 1 268,8-1 268,9 m, Oandu aukštas. E - ventralinès geldelès vidaus ne visa geldelè, GIT 716-440, Kybartų-29 gręžinys, gylis 1 275,9 m, Oandu aukštas. F - dalies ventralinès geldelès vidaus vaizdas, GIT 716-226, Pajevonys-13 gręžinys, gylis 1 188,9-1 189,0 m, Rakverès reg. aukšto Jakšių svita. G - dorsalinès geldelès vidus GIT 716-232, Pajevonys-13 gręžinys, gylis 1 192,0-1 192,2 m, Oandu reg. aukštas, Šakių svita. H - ne visa dorsalinè geldelè, GIT 715-231: H1, H2 kardinalijų vaizdai, kairysis brachioforas nulaužtas, ant dešinio brachioforo yra ilga sparno pavidalo atauga, nukreipta žemyn nuo interarëjos priešakinio krašto, Pajevonys-13 gręžinys, gylis 1 192,0-1 192,2 m, Oandu reg. aukštas, Šakių svita. 


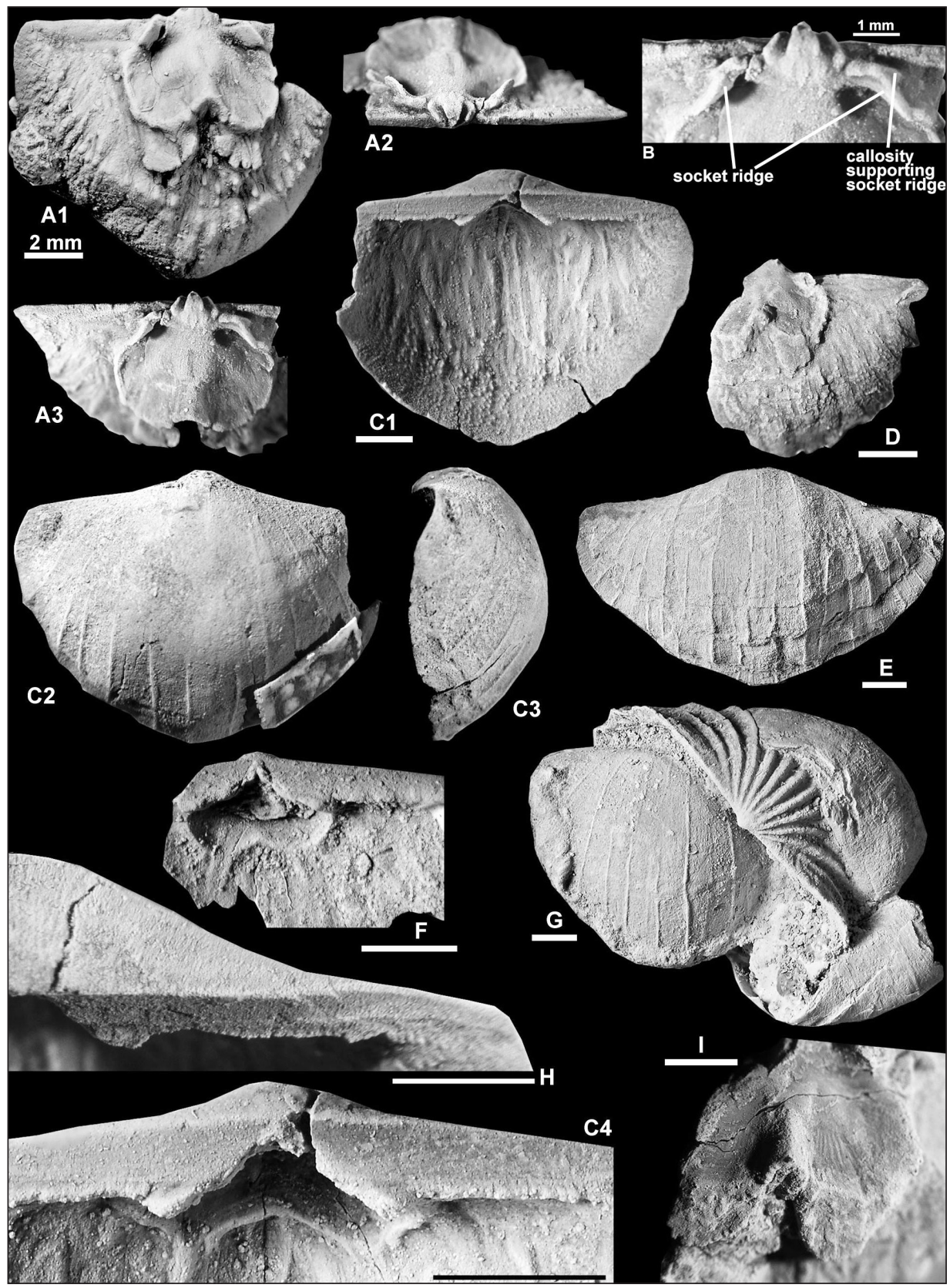

2 pav. Sampo suduvensis (Paškevičius, Hints, 2016)

A1-A3 holotipas, dorsalinės geldelès, VU, B14/23 išorè, kardinalijų ir bemos užpakalinis vaizdas, Kalvarijos-2 gręžinys, gylis 900,3 m, Rakverès reg. aukštas, Jakšiu svita. B - Sampo hiiuensis Öpik, dorainès geldelès vidus, Estijos geologijos instituto kolekcija, GIT 675-340, Estija, Kõrgessaare, Hiiumos sala, viršutinis ordovikas, Vormsio reg. aukštas. C - Sampo suduvensis, Paškevičius ir Hints: C1-C3 ventralinès geldelès, VU, B14/24 vidus, išorè ir lateralinė padètis, C4 - interarėjos vaizdas su dantukais šalia priešakinio krašto, Kalvarijos-2 gręžinys, gylis 900,3 m, Rakverès reg. aukštas (?), Jakšių svita. D - ne visos dorsalinės geldelès vidus, GIT 716-400, Kybartų-29 gręžinys, gylis 1 266,9 m, Oandu reg. aukštas, svita nenustatyta. E - ventralinès geldelès išorè, GIT 716-82, Pajevonio-13 gręžinys, gylis 1 193,2-1 193,3 m, Oandu reg. aukštas, Šakių svita. F - ne visos ventralinės geldelès vidaus vaizdas, VU, B14/28, Kalvarijos-2 gręžinys, gylis 900,3 m, Rakverès reg. aukšto (?), Jakšiu svita. G - ventralinė geldelè, VU, B14/45, B14/47 kartu su Nicolella sp. ventraline geldele, Kalvarijos-2 grę̌̌inys, gylis 900,3 m, Rakverès reg. aukšto (?), Jakšių svita. H - ventralinès geldeles GIT 716-54 interarejos vaizdas su dantukais pagal kraštą, Pajevonys-13 grę̌zinys, gylis 1 189,7-1 189,8 m, Oandu reg. aukštas, Šakių svita. I - dorsalinès geldelès fragmentas, bemos vaizdas, GIT 716-70, Pajevonys-13 gręžinys, gylis 1 190,0-1 190,6 m, Oandu reg. aukštas, Šakių svita. 
Thaerodonta notabile (Notabile (lot.) - jzžymi) (Paškevičius, 2016) priklauso tam pačiam būriui ir antšeimiui kaip ir Sampo, Sowerbellidae šeimai, Sowerbellinae pošeimiui, Thaerodonta genčiai, holotipas VU, B6,15/85, visas kiautelis, 3 paleontologinis pav., A1-A5, Nabalos reg. aukštas, Kaimynų svita, viršutinis ordoviko kačio aukštas (Paškevičius, 2016). Paplitusi Lietuvos facijų zonos, Vidurio Lietuvos ịlinkyje, Kaimynų svitos, Nabalos reg. aukšto molingose klintyse, rečiau sutinkama Vormsio reg. aukšto klintyse, tos pačios facijų zonos Baltarusijos vakarinejje dalyje.

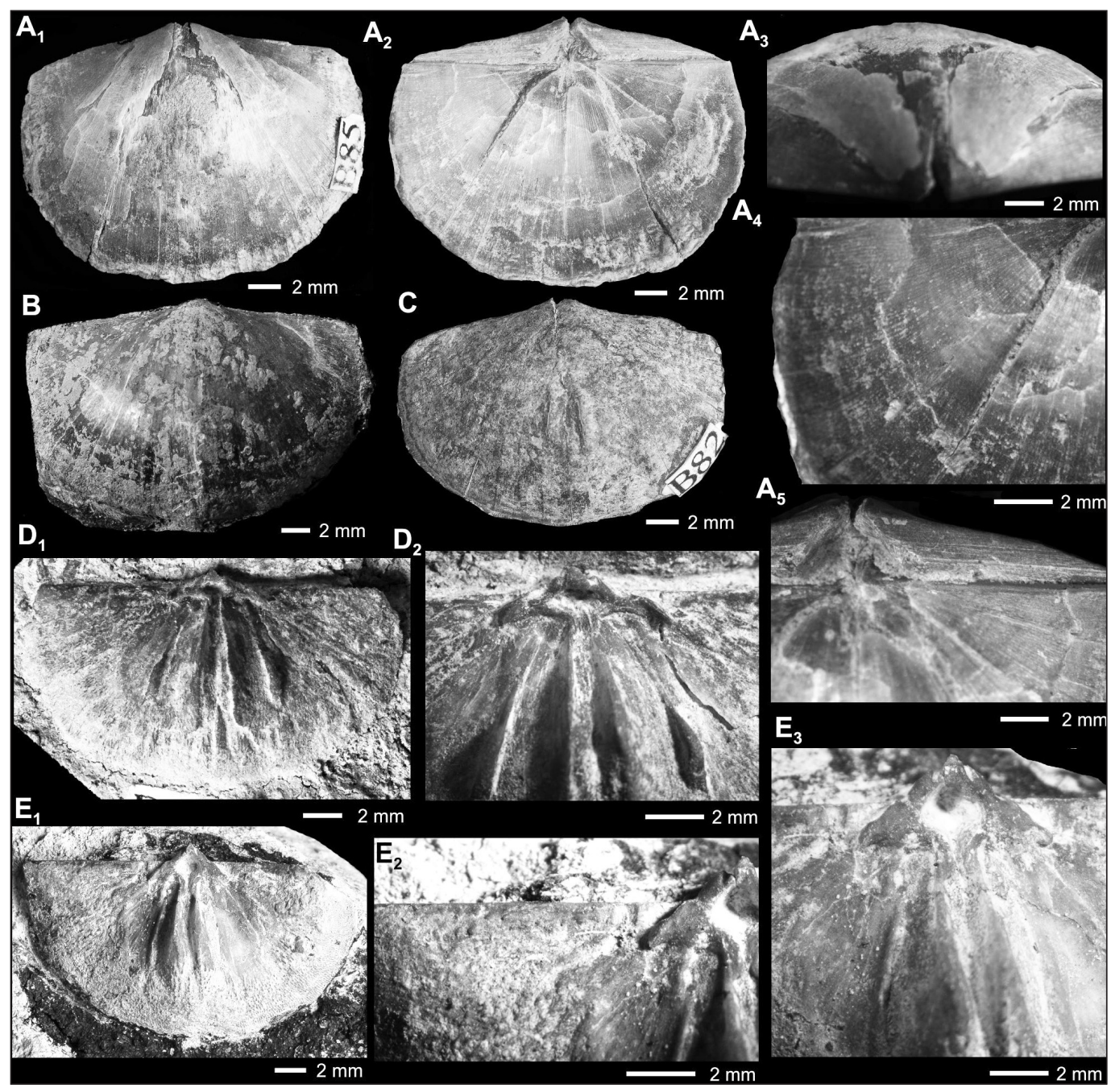

3 pav. Thaerodonta notabile (Paškevičius, 2016)

A1-A5 visas kiautelis, holotipas, VU, B6,15/85: A1 - ventralinė kiautelio geldelè plačiai išgaubta vidurinėje dalyje, A2 - dorsalinè kiautelio geldelè su interarèja ir deltyriumu, A3 - kiautelio išgaubimas, A4 - dorsalinès geldelès paviršiaus skulptūra su pirmos ir antros eilès kosteliais (spinduliais), A5 - ventralinès geldelès interarëja, pažeistas spynos mechanizmas, Taučionių-49 gręžinys, gylis 406,9 m, Nabalos reg. aukštas, Kaimynų svita. B - ventralinės geldelès, VU, B6,15/88, paviršiaus skulptūra, Taučionių-49 gręžinys, gylis 412,3 m, Nabalos reg. aukštas, Kaimynų svita. C - ventraliné geldelè, VU, B6,15/82, paveikta diagenezès ir epigenezès, todèl paviršiaus skulptūros nematyti, Kauno Vokès-1 gręžinys, gylis 283,0 m, Nabalos reg. aukštas. D1 - dorsalinès geldelès, VU, B6,15/90, vidinė sandara. D2 - dorsalinès geldelès spynos mechanizmas; kardinalinis procesas, nototyriumas, brachioforai ir kt., Taučionių-49 gręžinys, gylis 412,3 m, Nabalos reg. aukštas, Kaimynų svita. E1 - dorsalinės geldelės, VU, B6, 15/87 vidinè sandara. E2 - dorsalinès geldelès spynos kraštas su pastebimais mažais suapvalintais dantukais. E3 dorsalinės geldelès spynos mechanizmas: kardinalinis procesas, nototyriumas, brachioforai ir kt., Taučionys-49 gręžinys, gylis 409,8 m, Nabalos reg. aukštas, Kaimynų svita. 


\section{SILŪRO BRACHIOPODŲ RŪŠYS}

Lietuvos ir kitu kraštų silūre (Paškevičius, 1958; Pashkevichius, 1962; Paškevičius ir kt., 2002) taip pat buvo paskelbtos trys naujos brachiopodų rūšys (žr. šių rūšiu paleontologinị aprašymą).

Isorthis ovalis (Ovalis (lot.) - ovalo forma) (= Platyorthis ovalis) (Pashkevichius, 1962) pri- klauso Orthida būriui, Enteletacea antšeimiui, Isorthidae šeimai, Isorthis genčiai. Holotipas VU, 6/158c, visas kiautelis, 4 paleontologinis pav., B1B2, Jūros svita ir reg. aukštas, pržidolio skyrius. Paplitusi Lietuvos įlinkio vakarinèje ir vidurineje dalyse, pržidolio, Minijos ir Jūros svitose, Vakarų Latvijoje to pačio skyriaus ir svitų sluoksniuose (Gailite ir kt., 1967), autoriaus duomenimis, Estijos

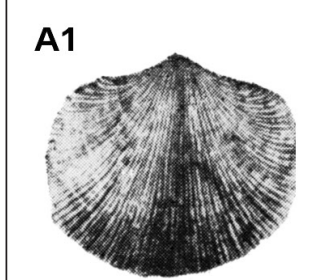

$1 \mathrm{~cm}$
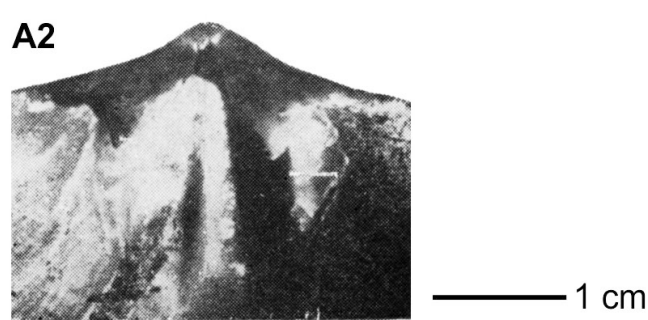

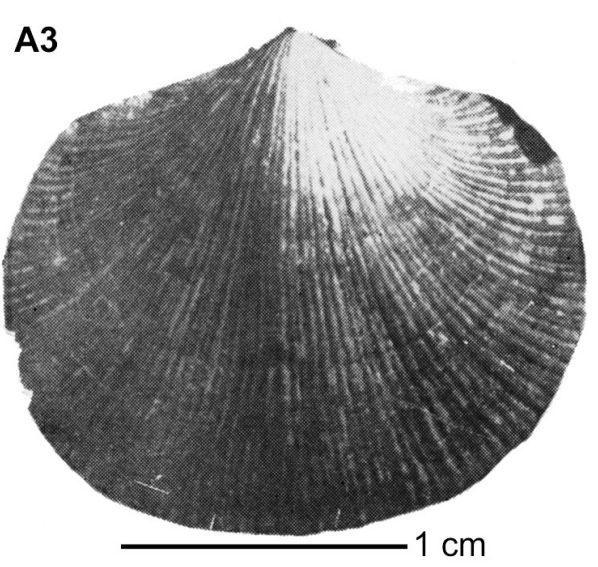

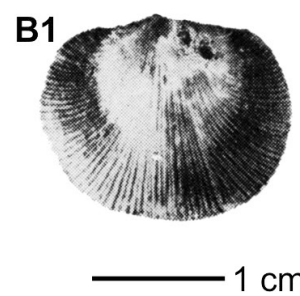

B2
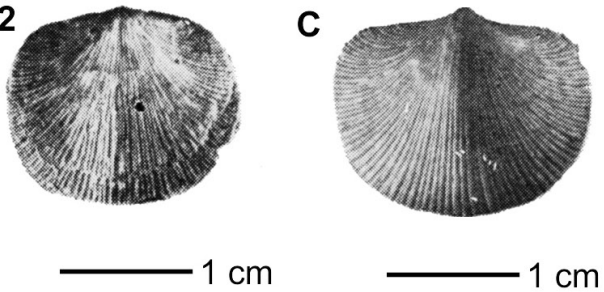

$\mathbf{F}$

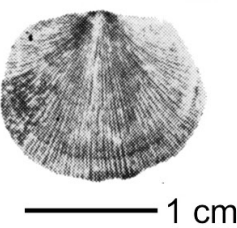

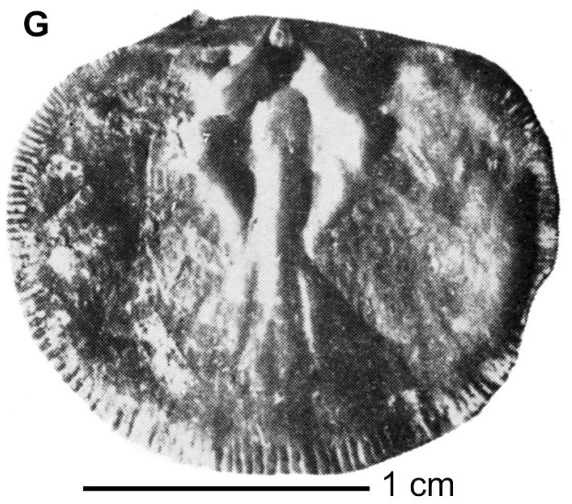

D

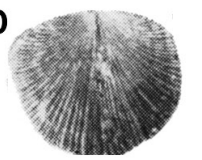

E

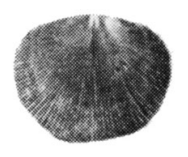

H

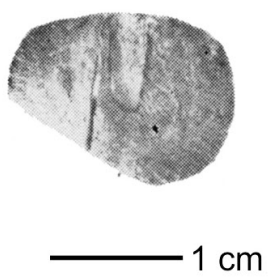

I

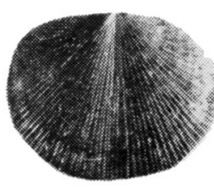

$-1 \mathrm{~cm}$

4 pav. Isorthis ovalis (Paškevičius, 1962)

A1 - ventralinė geldelè, B6/158a, smulki radialinè skulptūra. A2 - tos pačios ventralinès geldelès vidinė sandara, A3 - ta pati tik padidinta ventralinè geldelè, Virbalio-5 gręžinys, gylis 735,0 m, pržidolio skyrius, Jūros svita. B1 visas kiautelis, jo ventralinė geldelè, B6/158c, holotipas, B2 - tas pats kiautelis, jo dorsalinè geldelè, Stoniškių-1 gręžinys, gylis 1340,0 m, pržidolio skyrius, Jūros svita. C - ventralinė geldelè, B6/158d, Virbalio-5 gręžinys, gylis 731,73 m, pržidolio skyrius, Jūros svita. D, E, F, I - dorsalinès geldelès, platus sinusas, Virbalio-5 gręžinys, gylis 742,9-743,3 m, pržidolio skyrius, Jūros svita. G - dorsalinès geldelès vidinè sandara, B6/158 b, Virbalio-5 gręžinys, gylis 749,9 m, pržidolio skyrius, Jūros svita. 
Saremos salos to pačio skyriaus, Kaugatumos ir Ohesarès svitose, Podolès silūro, pržidolio skyriuje, Dzvinogorodo svitoje. Jų sankaupos kartais sudaro biomorfines klintis, gerai išlikę kiauteliai, pavienès, atsiskyrusios geldelès, randami melsvai pilkuose mergeliuose ( 4 pav.).

Strophochonetes stonishkensis (iš Vakarų Lietuvos miestelio ir gilaus gręžinio Stoniškiai pavadinimo) (Paškevičius, 1958; papildyta Rybnikova, 1967; Gailite ir kt., 1967) priskiriama Productidae būriui, Chonetacea antšeimiui, Chonetidae šeimai, Strophochonetes genčiai. Lektotipas išrinktas autoriaus 2017 m., VU, B6/2, visas kiautelis, 5 pav., B1-B3 iš Minijos svitos ir reg. aukšto, pržidolio skyriaus (Paškevičius, 1958, dis.). Paplitusi Vakarų ir Vidurio Lietuvos ilinkio Minijos ir Jūros svitose, Vakarinèje Latvijoje, tose pačiose svitose (Gailite ir kt., 1967).
Lissatrypa lithuanica (iš Lietuvos pavadinimo) (Paškevičius, Modzalevskya, Musteikis, 2002) priklauso Atrypidina pobūriui, Atrypoidea antšeimiui, Lissatrypidae šeimai, Lissatrypinae pošeimiui, Lissatrypa genčiai. Holotipas B10220, VU16, B1-13 paratipai, geldelès susijungusios, holotipo kiautelis, 6 pav., F1-F4 (egzempliorius iš įvairių padéčių), Rygos svita, uenlokis, homerio aukštas, lundgreni zona. Paratipai - Parovejjos-9 gręžinys, Rygos svita. Paplitusi Rytu Lietuvos, Paprienio ir Birštono svitose, Vidurio Lietuvoje, Rygos svitos (šeivūdžio viršutinès dalies ir homerio aukštuose) melsvai pilkuose mergeliuose.

\section{EKOLOGINĖS GYVENIMO SĄLYGOS}

Naujos brachiopodų rūšys gyveno seklesnèse šiltose jūrose, nes buvusi Lietuvos teritorija įejo $\mathfrak{i}$

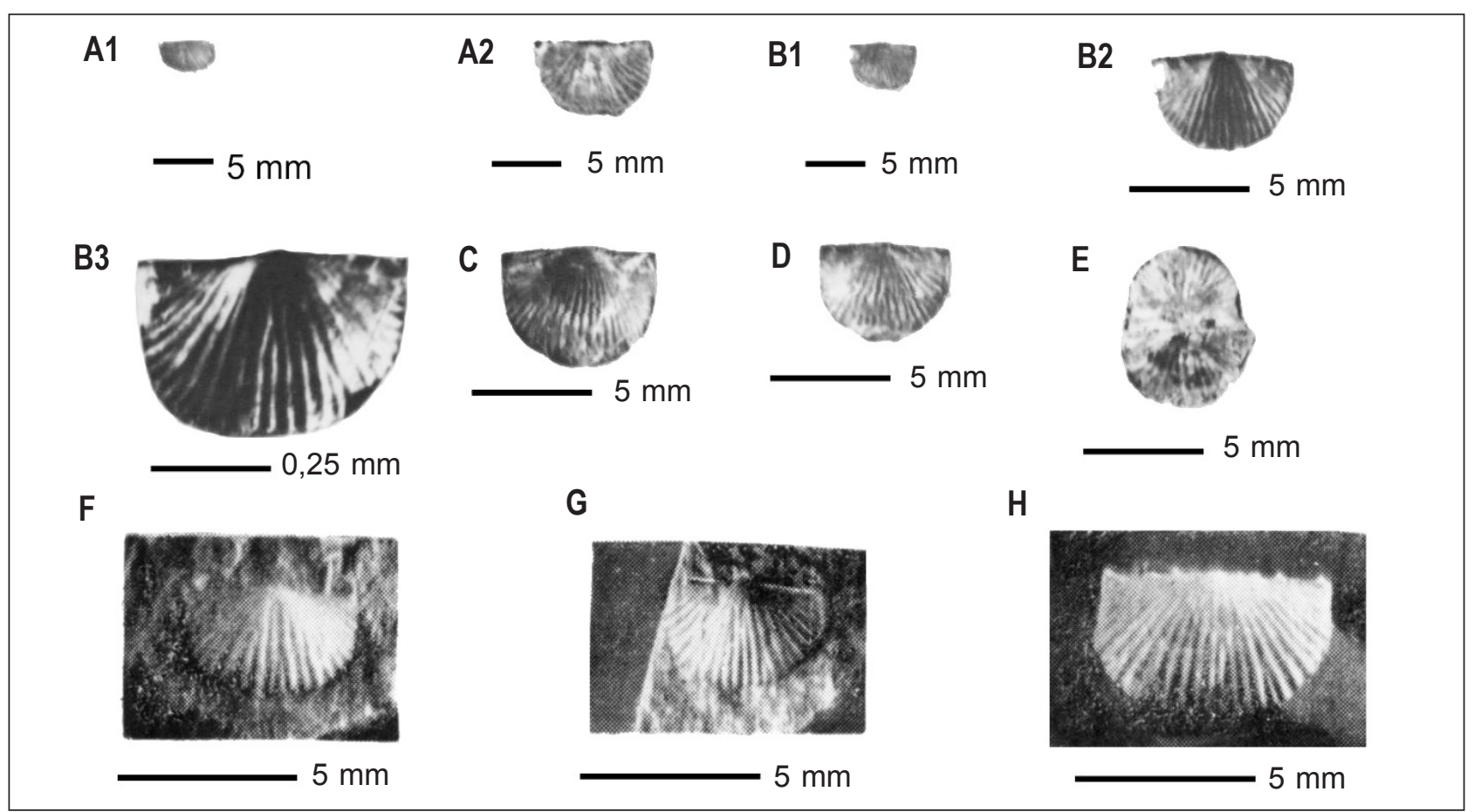

5 pav. Strophochonetes stonishkensis (Paškevičius, 1958; papildyta Rybnikova, 1967)

A1 - ventralinè geldelè natūralaus dydžio, Vladimirovo-1 gręžinys, gylis 1 503,0-1 808,0 m, pržidolio skyrius, Minijos svita. A2 - ta pati padidinta ventralinė geldelè, paviršiaus radialinė skulptūra, užpakaliniame krašte stebimos septynios spygliukų prisitvirtinimo vietos. B1 - ventralinės geldelès vaizdas. B2 - ventralinè geldele, jos paviršiaus skulptūra; B3 - padidinta ventralinè geldelè labiau išgaubta vidurinèje dalyje, lektotipas, B6/164. C - ventralinė geldelè. D - ventralinè geldelè. E - kiautelio neatsiskyrusios ventralinė ir dorsalinė geldelès, Stoniškių-1 gręžinys, gylis 1 424,0-1 482,0 m, pržidolio skyrius, Minijos svita. Latvijos duomenys (Rybnikova, 1967): F - ventralinè geldelè Br. 30/106 su vertikaliais užpakalinio krašto spygliukais, Ezerès gręžinys, gylis 993,0 m. G - ventralinė geldelè, Br. 30/107, Piltenès-1 gręžinys, gylis 598,3 m. H - visas kiautelis, ventralinė pusė, Br. 30/103, Ezerès gręžinys, gylis 1002,1 m, pržidolio skyrius. 


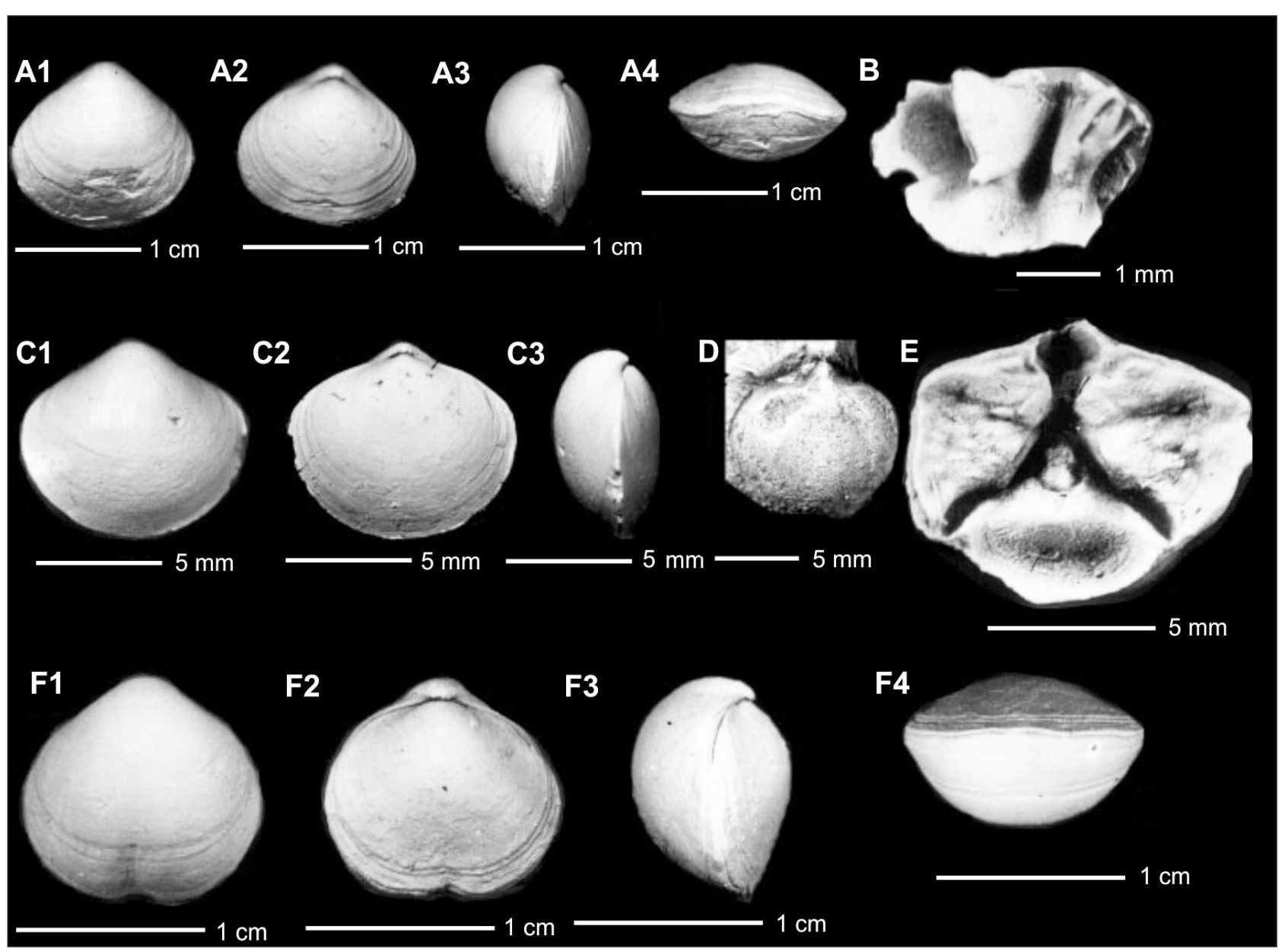

6 pav. Lissatrypa lithuanica (Paškevičius, Modzalevskaya, Musteikis, 2002)

A1-A4 - ventralinè ir dorsalinè pusès, lateralinis ir priešakinis kiautelio vaizdas, B10195, Sutkų-87 gręžinys, 352 pavyzdys, gylis 871,9 m, Rygos svita. B - ventralinès geldelès vidinis vaizdas, B10219, Gèluvos-99 gręžinys, 167 pavyzdys, gylis 906,9 m, Rygos svita. D - ventralinès geldelès vidus, B10108, Krekenavos-7 gręžinys, gylis 770,9 m, uenlokio skyrius, Paprienio svita, Vilkijos sluoksniai. C1-C3 - visas kiautelis iš ventralinès, dorsalinès ir lateralinès pusès, B10222, Gèluvos-99 gręžinys, 166 pavyzdys, gylis 907,8 m, Rygos svita. E - ventralinės geldelès vidus, B10168, Svèdasų-252 gręžinys, 109 pavyzdys, gylis 535,5 m, Švenčionių (?) svita. F1-F4, B10220 - holotipas, visas kiautelis iš ventralinès, dorsalinè, lateralinès ir priešakinès pusès, Gẻluvos-99 gręžinys, 151 pavyzdys, gylis 919,0 m, Rygos svita. Kolekcijoje VU16, B1-13 yra paratipai, Parovejos-9 gręžinys, gylis 562,8 m, Rygos svita.

senajj Baltikos kontinentą, kuris ordoviko ir silüro perioduose, prieš 485,4-419,2 milijonus metų, buvo arti pusiaujo. Tose jūrose brachiopodai sudarè sèslųjị bentosą (dugno gyvūnija). Brachiopodų ekologinès gyvenimo sąlygos labai skirtingos, suteikiančios galimybę îsigilinti ị jų ịvairovę, o tai galima kur kas detaliau atkurti ir pačio baseino ekologines sąlygas.

\section{ORDOVIKO RŪŠYS}

Paminètas dvi ordoviko naujas rūšis Dolerorthis nadruvensis (Paškevičius, Hints, 2016) ir Sampo suduvensis (Paškevičius, Hints, 2016) reikia skirti
Howelites wesenbergensis-Hedstroemina subaequiclina-Reuschella magna bendrijai (Paškevičius, 2000). Jos amžius yra Kačio aukštas, Oandu regioninis aukštas, Alvito ir Šakių svitos arba vienalaikẻ Lukšių svita. Ši bendrija išsiskiria paleogyvūnijos rūšių ir tos pačios rūšies individų gausa, ypač brachiopodų. Taip pat bendrijoje yra bryozojų, trilobitų, ostrakodų, konodontų, pasitaiko graptolitų. Bendrijos tipinè vietové yra Pajevonio-13 gręžinio 1 194-1 202 metrų gylyje, papildoma Kalvarijos-2 gręžinyje, tai Vidurio Lietuvos įlinkio vakarinis šlaitas. Uolienos, kuriose palaidoti bendrijos individai, yra karbonatiniai 
moliai, mergeliai su biomorfinių klinčių tarpsluoksniais, kurių storis siekia 19 metrų. Ši bendrija vystėsi gilèjančiame šelfiniame baseine, jūrai transgresuojant rytų-pietryčių kryptimi. Vyraujant karbonatinems-molingoms facijoms ir plonasienèms, rečiau pastorèjusioms, kiautelių sienelèms - brachiopodams, bendrija formavosi šelfo facijose, bentoso bendrijų standartas BA4. Bendrijoje vyrauja sveikos brachiopodų geldelès, o tai susiję su maža vandens dinamika. Organizmų sankaupos atspindi geras jų gyvenimo sąlygas, t. y. ne itin gilus baseinas, dar pakankama priedugnio aeracija, mažejantis, bet ne kritinis brachiopodams vandens karbonatingumas.

Vèlesnèse bendrijose: Platystrophia lutkevichi satura, Wisogorskiela litvensis - Dinorthis solaris - Isorthis estona vystèsi nauja rūšis Thaerodonta notabile (Paškevičius, 2000). Jų amžius - Kačio aukštas, Nabalos aukštas, Paeknos-Kaimynų svitos, retai sutinkama Vomsio reg. aukšte. Šių bendrijų brachiopodai buvo palaidoti pilkose, molingose, detritinèse klintyse su mergelio tarpsluoksniais, seklaus šelfo facijos baseine. Bentoso bendrijos standartas BA2-BA3. Šio baseino vanduo buvo šiltas, normalaus druskingumo, aktyvi vandens turbulentinè dinamika, priedugnis dar pakankamai aeruojamas, tačiau pasitaiko ir silpnos redukcinès aplinkos, o tai rodo reti piritizuoti sluoksniavimosi paviršiai (Paškevičius, 2000, 2012).

\section{SILŪRO RŪŠYS}

Lissatrypa obovata - Skenidioides lewisi bendrija (Musteikis, Paškevičius, 1999). Jos sudètyje yra Lisstrypa lithuanica (Paškevičius, Modzalevskaya, Musteikis, 2002) rūšis. Ši bendrija vystėsi Bentoso bendrijos standarto BA4-BA5 sąlygomis. Rūšis dominuoja bendrijoje. Paplitusi uenlokio skyriuje, Rygos ir kitose svitose kartu su retais graptolitais, trilobitais. Bendrijos individai palaidoti tamsiai pilkuose ir pilkuose mergeliuose su mikrokristalinių klinčių intarpais. Bendrija vystėsi neaerobinèmis, rečiau normaliomis aerobinèmis sąlygomis, esant vidutiniam vandens turbulentiškumui, normaliam arba žemam deguonies kiekiui.

Isorthis ovalis bendrija. Joje paplitusi bendrijos nominalinè rūšis, taip pat ir Strophochonetes stonishkensis (Paškevičius, 1958; papildyta Rybni- kova, 1967). Ši bendrija paplitusi Vakarų ir Vidurio Lietuvoje, pržidolio skyriaus Minijos ir Jūros svitose. Jai būdingas vidutinis vandens turbulentiškumas, BA3 bentoso bendrijos standartas, dominuojanti Isorthis ovalis rūšis yra randama su kitais plonasieniais brachiopodais, ostrakodais, trilobitais, crinoidejomis, gastropodais, bryozojais, bivalvijomis. Paminèta fauna palaidota melsvai pilkuose mergeliuose su biomorfinių-detritinių klinčių tarpsluoksniais. Kiautelių geldelès dažniau atskirtos, sveikos geldelès retesnès. Apskritai geldelès gerai išlikusios (Musteikis, Paškevičius, 1999).

\section{LEIDINIAI, KURIUOSE PUBLIKUOTOS NAUJOS BRACHIOPODŲ RŪŠYS, APRAŠYTAS JŲ SAUGOJIMAS}

Naujos brachiopodų rūšys buvo publikuotos autoriaus kandidatineje disertacijoje (1958), Lietuvos MA Geologijos ir geografijos instituto žurnale „Moksliniai pranešimai“ (1962), Lietuvos mokslų akademijos mokslo žurnaluose „Geologija“ (2000) ir „Geologija. Geografija (2016), Didžiosios Britanijos geologijos mokslui skirtame žurnale „Palaeontology“ (2002), Estijos žemès mokslų žurnale „Earth Sciencies of Estonia“ (2016) (žr. literatūra). Autoriui skelbiant šią naują medžiagą talkino Vilniaus universiteto doc. Petras Musteikis, Sankt Peterburgo geologijos instituto mokslo darbuotoja Tatjana Modzalevskaja, Estijos geologijos instituto mokslinè bendradarbė Linda Hints, Latvijos jūrų geologijos instituto mokslinè darbuotoja Margarita Rybnikova.

Naujų rūšių holotipai ir paratipai yra saugomi Vilniaus universiteto Geologijos ir mineralogijos katedros Geologijos muziejuje. Tam yra skirta atskira vitrina.

\section{BRACHIOPODŲ KOLEKCIJOS, RŪŠIŲ HOLOTIPŲ NUMERIAI}

Kolekcija 14 - Dolerorthis nadruvensis (Paškevičius, Hints, 2016), Nr. B14/66.

Kolekcija 14 - Sampo suduvensis (Paškevičius, Hints, 2016), Nr. B14/23.

Kolekcijos 6, 15 - Thaerodonta notabile (Paškevičius, 2016), Nr. B6/85 (B15/85).

Kolekcija 6 - Isorthis ovalis (Paškevičius, 1962), Nr. B6/158c. 
Kolekcija 6 - Strophochonetes stonishkensis (Paškevičius, 1958; papildyta Rybnikova, 1967), B6/2.

Kolekcija 6 - Lissatrypa lithuanica (Paškevičius, Modzalevskya, Musteikis, 2002), B10220, paratipai B16/1-13.

\section{PADE்KA}

Autorius nuoširdžiai dèkoja Lindai Hints (Estijos geologijos institutas), Tatjanai Modzalevskajai (Rusijos geologijos institutas, VSEGEI, Sankt Peterburgas), Petrui Musteikiui (buvusiam Vilniaus universiteto darbuotojui), prisidejusiems prie Lietuvos naujų brachiopodų rūšių tyrimo, taip pat Sigitui Radzevičiui už pagalbą rengiant paleontologinius paveikslus.

Gauta 20170404

Priimta 20170612

\section{LITERATŪRA}

1. Gailite L. K., Rybnikova M. B., Ulst R. Zh. 1967. Stratigrafya, fauna i uslovya obrazovanye siluryskikh otlozhenii Centrlney Pribaltiki. Riga: Zinatne. 554 s. 32 paleontol. tabl. [rusų k.].

2. Hints L., Paškevičius J., Martma T., Männik P., Nolvak J. 2016. Upper Sandbian-Lower Katian chemostratigraphy in the Paevonys-13 core, Lithuania. Estonian Journal of Earth Sciences. 65(2): 85-97.

3. Musteikis P., Modzalevskaya T. L. 2002. Some Silurian Brachiopods from Lithuania and their Palaeogeographic significance. Palaeontology. 45(3): 595-626.

4. Musteikis P., Paškevičius J. 1999. Brachipod Communities of the Lithuanian Silurian. Paleocommunities - a case study from the Silurian and Lower Devonian. Eds. By A. J. Boucot and J. D. Lawson. World and Regional Geology. II. Cambrige University press. 305-326.

5. Paškevičius J. 1958. Pietinio Pabaltijo ordoviko-silūro dariniu stratigrafija ir fauna. I tomas, 331 p., 5 paleontol. lent.; II t. grafiniai priedai, 19 brèž.
Geol. ir miner. mokslų kand. dis. Vilniaus universitetas.

6. Pashkevichius J. 1962. Plathyorthis ovalis sp. novyie stratigraficheskoe znachenye $\mathrm{v}$ otlozheniyakh verkhnego ludlova Yuzhnoy Pribaltiki. In-t geol. i geogr. AN Lit. SSR. Naych. soobshhcheniya, t. XIV. 33-47 [rusų k.].

7. Pashkevichius J. 1963. Stratigraficheskaya reviziya siluriyskikh karbonatnykh otlozhenii Yuzhnoy Pribaltiki. In-t geol. i geogr. AN Lit. SSR. Vprosy geologii Litvy. Vilnius. 385-404 [rusų k.].

8. Pashkevichius J. 1968. Biostratigrafiya i koreliaciya siluriyskikh terigennykh i karbonatnykh otlozhenii Yuzhnoy Pribaltiki. Stratigrafiya nizhnego paleozoya Pribaltiki i koreliaciya s drugimi regionami. XXIII sessiya MGK. Vilnius: Mintis. 250-272 [rusuc k.].

9. Pashkevichius J. 1972. Biostratigrafiya, koreliaciya i graptolity ordovikskikh i siluriskikh otlozhenii Yuzhnoy Pribaltiki. Dis. doktora geol.-miner. nauk. Vilnius, 1972, t. I, 399 s., t. II, 351 s., paleontol. tabl. 100 s. [rusų k.].

10. Pashkevichius J. 1973. Biostratigrafiya, koreliaciya i graptolity ordovikskikh i siluriskikh otlozhenii Yuzhnoy Pribaltiki. Autoref. dis. na soiskanie uch. Stepeni dr. geol-miner. $n .67$ s. Vilniuskii universitet. 67 s. [rusų k.].

11. Paškevičius J., Lapinskas P., Brazauskas A., Musteikis P., Jacyna J. 1994. Stratigraphic revision of the Regional Stage of the Upper Silurian part in the Baltic Basin. Geologija. 17: 64-87.

12. Paškevičius J. 2000. Baltijos ordoviko baseino, Lietuvos facijų zonos brachiopodų bendrijos. Geologija. 32: 14-35.

13. Paškevičius J. 2004. Ordoviko brachiopodai. Lietuvos Žemès gelmių raida ir ištekliai. Vilnius. 153-161.

14. Paškevičius J., Klimantavičius V., Radzevičius S. 2012. Litostratigraphy, Graptolites and Brachiopods communities of the Ludlow (Silurian) of the Baltic Syneclyse. Geologija. 54(3): 75-88.

15. Paškevičius J., Hints L. 2016. New Early Katian species of Leptestiidae and Hesperorthidae (Brachiopoda) from Lithuania. Estonian Journal of Earth Sciences. 65(2): 75-84.

16. Paškevičius J. 2016. Pecularities of the lithology and fauna Early Katian (Ordovician) in the Lithuanian facies zone. Geologija. Geografija. 2(2): 49-61. 


\section{Juozas Paškevičius}

\section{NEW SPECIES OF BRACHIOPODS IN LITHUANIA}

Sum mary

The paper briefs the environmental conditions on the Baltic Continent at the equator in the area of the would-be Lithuania during the Silurian and the Ordovician and describes deposits where the new brachiopod species are buried and gives their age as well as their investigation methods. The taxonomy, age, distribution and environmental conditions of new Ordovician species, such as Dolerortis nudruvensis Pašk. et Hints, Sampo suduvensis Pašk. et Hints and Thaerodonta notabile Pašk., as well as the Silurian Isorthis ovalis (Pašk.), Strophochonetes stonishkensis (Pašk.) emend. Rybn. and Lissatrypa lithuanica Pašk., Modz. et Must. are discussed. The sources where the new species have been published are presented, and the palaeontologists who investigated these species are indicated. The holotypes and paratypes of the new species are stored at the Geology Museum of Vilnius University. The palaeontological tables of 4 new spices have been constructed.

Keywords: brachiopods, Ordovician, Silurian, new species, taxonomy, age, distribution, ecology 